\title{
Spatial distribution of prenatal indicators in the State of Tocantins 2001 to 2015
}

Patrick Nunes Brito 1

https://orcid.org/0000-0002-1584-6063

Tássylla Caroline Ferreira Pereira 2

https://orcid.org/0000-0001-8754-4091

Durval Nolasco Neves Neto 3

https://orcid.org/0000-0003-1760-6685

Cristina Zanettini Ribeiro 4

https://orcid.org/0000-0002-5445-2198

1-3 Centro Universitário Tocantinense Presidente Antônio Carlos (UNITPAC). Av. Filadélfia, 568. Setor Oeste. Araguaína, TO, Brasil. CEP: 77.816-540. E-mail: patrick091979@hotmail.com

4 Instituto Tocantinense Presidente Antonio Carlos S/A. ITPAC Palmas. Palmas, TO, Brasil.

\begin{abstract}
Objectives: temporal-spatial analysis of prenatal indicators in the municipalities of the state of Tocantins based on the use of five-year intervals from 2001 to 2015.

Methods: the indicators subject to analysis were: average prenatal care $(A P C P W)$, proportion of prenatal care in the first trimester (PPCFT) and proportion of pregnant women with vaccine on time (PWVT). Data from the DATASUS platform were used for spatialization of indicators through Thematic Maps, using the QGIS software.

Results: indicators of proportion of prenatal care in the first trimester and proportion of pregnant women with vaccine on time showed gradual improvement in their indicators after 15 years of analysis, with values above $75 \%$ and $90 \%$, respectively, showing compatibility with the current national scenario. However, APCPW has revealed that no municipality had more than 3 prenatal care visits within 15 years.

Conclusions: among the indicators analyzed, the average of prenatal care, although it showed improvement in the 15-year interval, is the one with the greatest deficiency in the state and should therefore have a greater focus on primary care. Thus, it emphasizes the need to encourage the development of organized health systems and the use of specific policy actions to improve not only this indicator, but also the others, to improve prenatal quality.
\end{abstract}

Key words Primary health care, Prenatal care, Women's health

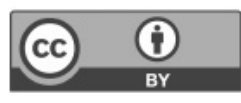




\section{Introduction}

In the early twentieth century, women, who correspond to most of the Brazilian population, had a very restricted role in Brazil, having only domestic and reproductive functions. In the first decades of the same century, childbirth and pregnancy care policies were instituted, stemming from the need to control the high mortality rate presented by women and children at the time, which lacked special information and care in the prenatal, childbirth and puerperium periods, reflecting low prenatal care and care for these groups. 1

According to estimates by the Brazilian Institute of Geography and Statistics (IBGE) in 2018, the Brazilian socio-demographic situation looked about 209 million inhabitants, of which approximately 106 million constituted the female population, which remains the predominant part of the population. ${ }^{2}$

Currently, women's health is a government priority, due to its role as an indicator of the level of equality and quality in a society, and due to this, it is embedded on the Unified Health System (UHS), a system which when acting in this specific axis, aims to meet the needs of the female population through resolutive actions and projects that guarantee quality and comprehensiveness in the care of this group. ${ }^{3}$

The women's health axis is incorporated into Primary Care, which is one of the areas of strategic action of the UHS. This measure has its importance in the search for greater follow-up and regular consultations for the female population when compared to the male population, and the strategic direction of this policy is supported in reality, where women show greater concern for their health and that of their families. 1

Prenatal care is allocated to women's health. Pregnancy is an important physiological event, a period that includes physical, emotional, social and psychic changes. ${ }^{4}$ Based on this period, prenatal care is performed preferably as early as possible, in order to allow the medical follow-up of this pregnant woman integrally providing her with information on how to maintain a healthy pregnancy and allowing proper periodic care. Early capture of pregnant women, periodicity of consultations, full coverage and quality of care are some indicators that help the service's effectiveness evaluation, which should be provided individually to pregnant women. ${ }^{1}$

Tocantins, the newest state of the Brazilian federation, presents, in general, a wide prenatal coverage, however the consultations's records reveal that the importance of prenatal is not yet widespread, and although there is an assistance, it still remains outside the recommended and desired parameters. ${ }^{5}$ In order to better evaluate the female population and the prenatal follow-up of this group, the objective of this study is to analyze the spatial and temporal distribution of prenatal indicators included in the Women's Health in Primary Care's axis, in Tocantins State.

\section{Methods}

This is a cross-sectional study under a quantitative approach from the perspective of the analysis of indicators related to family health in the state of Tocantins, based on qualitative involvement focused on public policies geared to health. The quantitative and qualitative intertwining makes it possible to discern the genesis of the problem. 6

Based on the spatial analysis, the study was conducted considering the state of Tocantins, the newest federative unit in the country, organized in 139 municipalities. ${ }^{7}$ The 139 municipalities of Tocantins were used in the study.

The digital cartographic meshes of the Tocantins's municipalities, used to facilitate the visualization of the advances of health services by territory, were obtained through the internet, from the Brazilian Institute of Geography and Statistics website, based on the archives of the politicaladministrative structure in 2013.

The study was based on prenatal indicators, included in the Primary Health Women's Health axis, analyzed on a municipal scale in the state of Tocantins, and evaluated in a chronological order of 15 years (2001 to 2015) being considered five-year equivalent intervals (2001 to 2005, 2006 to 2010 and 2011 to 2015) for analysis. The approach was based on the health indicators's analysis, as their capacity to be used as a way of monitoring services, since they allow the analysis of the health situation over the years, making it possible to compare the performance of actions. 8

The necessary guidance for the study was obtained from the Ministry of Health's manual "Qualifying Indicators of the Instruction Manual for the Primary Care (Family Health, Oral Health and Parameterized Teams) and NASF teams", 2015, with information from (1) production and markers of the Primary Care Information System (SIAB), (2) health situations in SIAB, (3) family registration in SIAB, (4) data from the Live Birth Information System (Sinasc), been collected through Department of Informatics of the Unified Health System (DATASUS) website, responsible for collecting, processing and disseminating health information. 
The Women's Health indicators selected for the study included three: the average prenatal care per registered pregnant woman (APCPW); proportion of pregnant women with prenatal care in the first trimester (PPCFT) and proportion of pregnant women with vaccine on time (PWVT). 9

The APCPW indicator allows the study of the supply and demand binomial, through the division of the number of prenatal care by the number of pregnant women registered in the municipalities of Tocantins in the above period. 5 The PPCFT indicator is obtained by dividing the number of pregnant women with prenatal care started in the first trimester by the total number of pregnant women in a given place and period. The indicator PWVT is obtained by the division of pregnant women with vaccine on time by the number of pregnant women registered in a given place and time frame. ${ }^{8-9}$

The collected data were organized and treated using descriptive statistics, allowing the previous understanding of the informationfor later spatialization and cartographic representation. Organized data from the Microsoft Office Excel version 2016 program was imported into the free software QGIS, version 2.18, a geographic information platform that allows the visualization, creation, editing and analysis of maps in various formats.

The geoprocessing performed was based on principles of graphic or neographic semiology for the development of information spatialization, through Thematic Maps for spatial representation of family health indicators. The principles of graphic semiology reveal that the data and statistical results triggered by the information, insufficient for decision making, are applied and analyzed together, 10 providing five-year interval maps.

The results were presented visually and described and analyzed transversally. The evaluation of the indicators was based on the most up-to-date parameters proposed by the Prenatal and Birth Humanization Program (PHPN - Portuguese acronym), from Ministry of Health.

\section{Results}

The temporal and spatial analysis of the APCPW (Figure 1) shows that in the interval from 2001 to 2005, most municipalities had the average of prenatal care attendance less than one, with a predominance of more attendances in the west. In the following period, from 2006 to 2010, the distribution in the number of visits shows a more homogeneous characteristic, increasing its number from one to two, with rare municipalities presenting higher values. In the last interval, 2011-2015, although no municipality had an average greater than three, there is a larger area of coverage, however still unsatisfactory, with the presence of municipalities that have less than one attendance.

The map analysis (Figure 1) allows a gradual increase in the indicator's quality from west to east (left to right), allowing to observe that municipalities closer to the state of Pará were more developed for this indicator. It should be noted that locations that already had some number of medical appointment tended to improve it, although for values below the desired minimum of six appointments, noting that the average number of medical appointments remained in the range of one to two.

Analysis of the PPCFT indicator (Figure 2) reveals that between 2001 and 2005 there was heterogeneity in the proportion of prenatal care started in the first trimester, with a greater predominance of early onset in the west of the state. In the following interval, 2006-2010, there was a significant increase in this proportion, highlighting that most municipalities that previously had at least $50 \%$ of their population with prenatal care in the first trimester advanced to $75 \%$ or more in this proportion. The interval between 2011 and 2015 shows a greater expansion in the proportion, where previously most of municipalities's higher proportions were in the west, now are more equitably displayed in all directions of the state, however some municipalities showed retrogression in their evolution when compared to the previous interval.

The spatial representation provided by the PWVT (Figure 3) in the first five years (2001 to 2005) shows that the vaccine's coverage for pregnant women is over $50 \%$ in all municipalities of Tocantins, with larger proportions located in the south and scarcer in the east. In the next five years, there is an almost uniform representation, with none of them having vaccination coverage below $60 \%$ in the state and only one with a proportion between $60 \%$ and $70 \%$, highlighting most of the municipalities with $90 \%$ to $100 \%$ in proportion for this indicator. In the last five years, this indicator improved in the municipalities located in the east, although the overall proportion of immunizations in pregnant women declined in the state, with some of them regressing to $50 \%$ to $60 \%$, a fact not observed in the previous interval.

The temporal analysis of the map (Figure 3) shows that at the beginning of 2001 the proportion of pregnant women with vaccine on time reached values near the maximum in many municipalities, a fact that was significantly improved in the following 
Map of Tocantins State - Average prenatal care per registered pregnant woman (APCPW) between 2001 to 2015

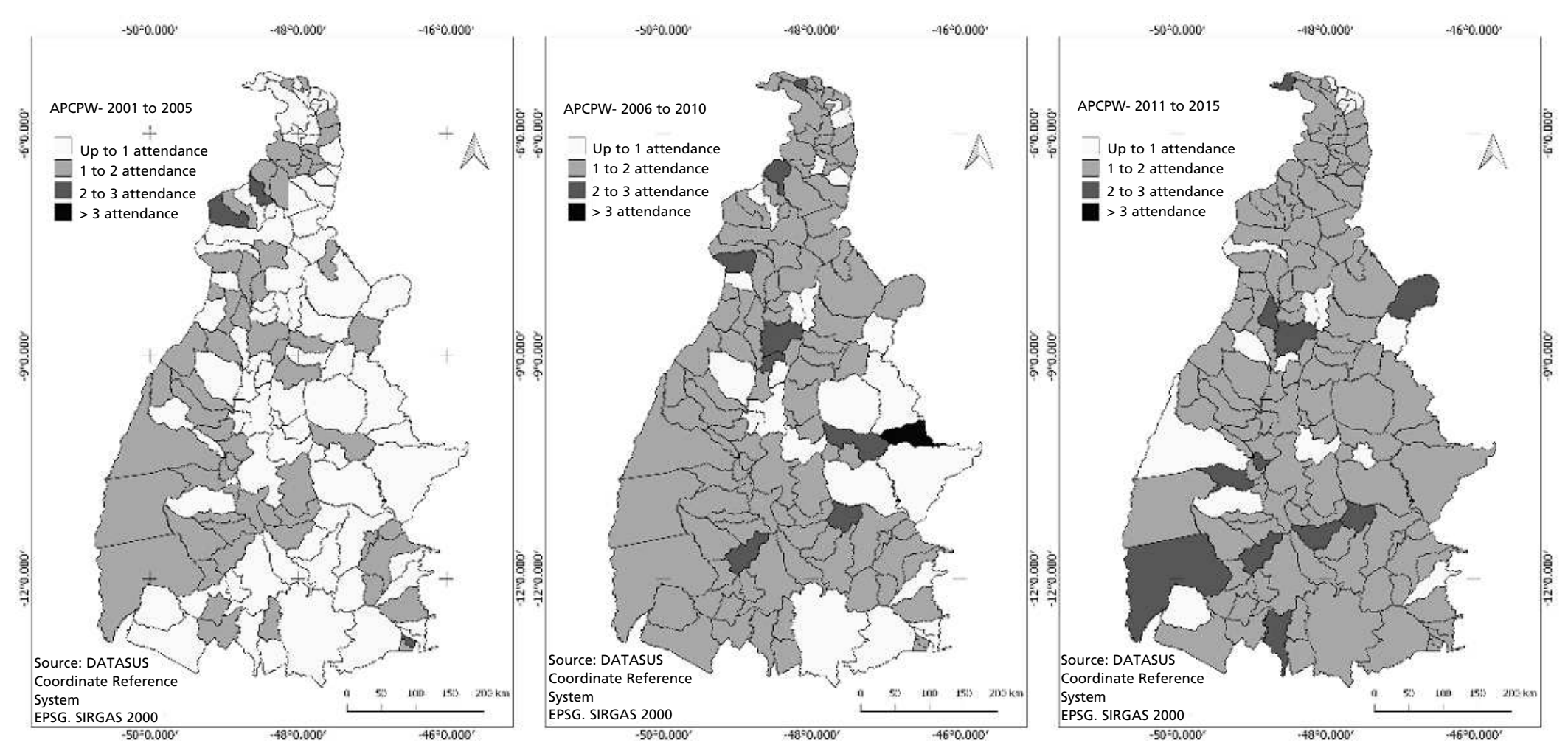




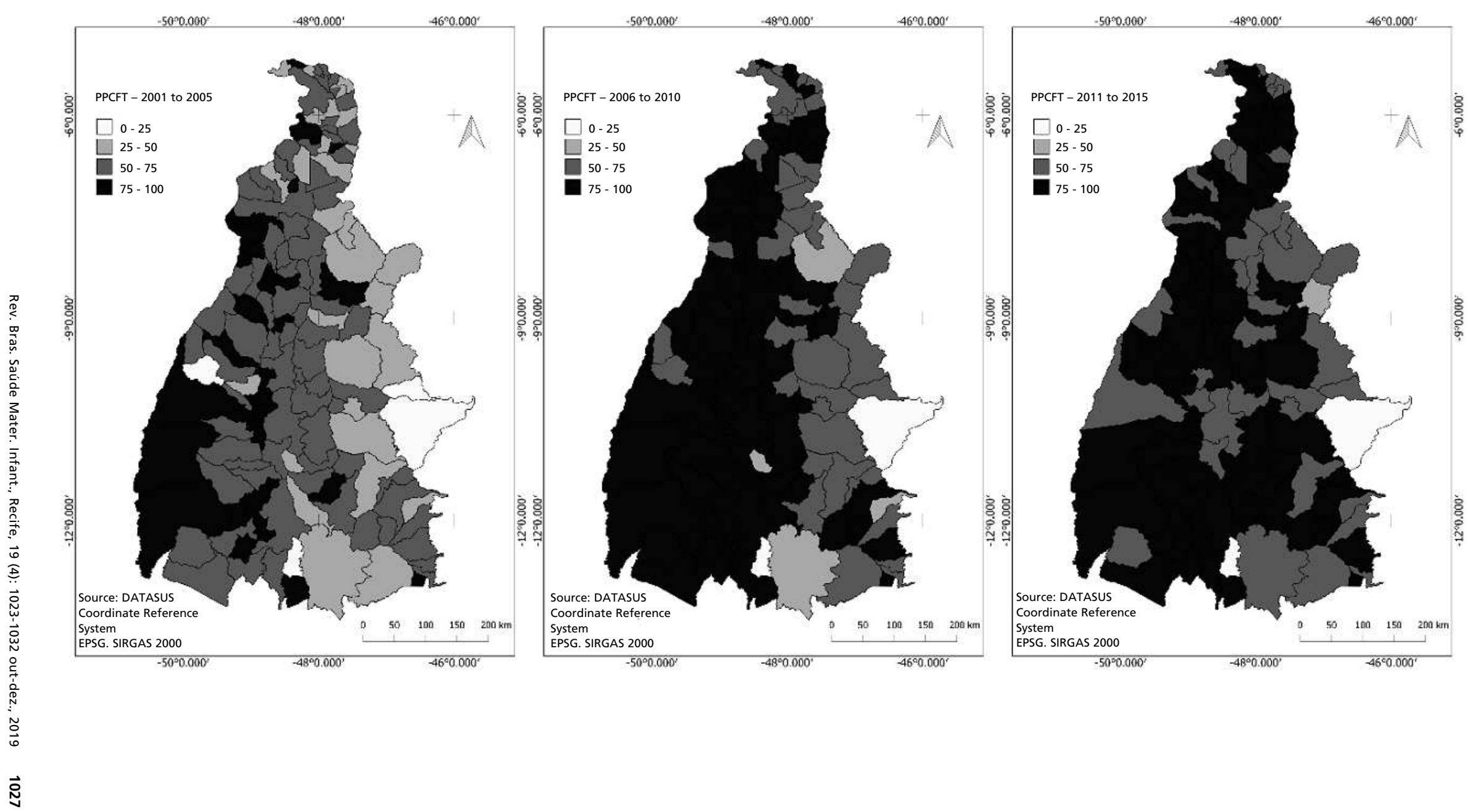


intervals, emphasizing that the best uniform and satisfactory representation was observed from 2006 to 2010 .

Table 1 shows the average value in the 15 years (2001 to 2015) of the three indicators analyzed in this study in the 10 largest cities of the state of Tocantins and the general average of the state itself. It is observed that the city of Palmas, although being Tocantins's capital, presented very low values for the APCPW indicator. However, it is emphasized again that none of the ten largest cities in the state presented values above the recommended for this indicator, minimum of six consultations. The analysis of PWVT for the ten largest cities shows that they have high average values, maintaining the proportion between $88 \%$ to $96 \%$.

\section{Discussion}

The study's result allows the evaluation of the municipalities of Tocantins about prenatal care, an important set of activities which,by means of health promotion to pregnant women and newborns associated with the prevention of obstetric complications, aims at reducing maternal and fetal morbidity and mortality. 11 The focus is on the analysis inwomen's health indicators, considering, in an unprecedented way, the average attendance per pregnant woman registered, proportion of pregnant women with prenatal care in the first trimester and proportion of pregnant women with vaccine on time in the state.

The adequation in the average prenatal care per registered pregnant woman - APCPW (Figure 1) is seen through ordinance no. 569, June 1, 2000, where the Ministry of Health recommends that a desired prenatal should be made up of at least six consultations, 12 which is one of its goals. The demonstration of lower than desired values at the very beginning of the $21^{\text {st }}$ century can be attributed to the immaturity of public health policies, because, while PHPN already existed, there was a need for better structuring to ensure its effectiveness and clear descriptions of how to implement actions. The values in the third interval (2011 to 2015) show diffusion of prenatal care policies, which may reflect the implementation of Rede Cegonha (Stork Network), by the Ministry of Health in 2011, a primary care strategy to ensure greater assistance in prenatal, postpartum and development until the first two years of life. 13 This strategy, based on broadening access to health services and delimiting state vulnerability points to tailor specific local strategies may haveprovided an important contribution to this improvement. 14

The analysis of this indicator contributes to the elaboration of care protocols and practical measures to improve it. 15 Among the improvements to be developed to increase the number of attendances, education deserves special attention, since low level of education compromises quality in prenatal care and represents an obstacle to adherence ${ }^{16}$; as well as updating the user registry, in order to ensure effective monitoring of the indicator and to provide continuous assistance through the active search of pregnant women in home visits and the search for negligent pregnant women for consult. ${ }^{9}$ The appropriate number of consultations during pregnancy enables appropriate follow-up and timely interventions whenever necessary, avoiding complications to maternal and fetal health. ${ }^{17}$

The indicator of the proportion of pregnant women with prenatal care in the first trimester PPCFT (Figure 2) allows the assessment of early access to prenatal care. The Ministry of Health, through the registries of primary care, advocates that a quality prenatal care should start by the $12^{\text {th }}$ week of pregnancy, featuring early uptake. 18

The cartographic analysis of Figure 2 shows the progress occurred in 15 years of intensification in early prenatal care in the first trimester, which, though, the PHPN were at initiation stage in the first five-year period analyzed (2001-2005), it was observed prevalence greater than $50 \%$ in the proportion of pregnant women with early prenatal care, probably due to the strengthening of campaigns promoted by the Family Health Program (PSF Portuguese acronym), set up by the Ministry of Health in 1994 and aimed at the reorganization of health-related services, which also included prenatal care. 19

Finally, in the last five years, the association of PHPN and the recent Family Health Strategy (ESF Portuguese acronym, formerly PSF) allowed the propagation of active actions in early capture throughout the state, in order to meet the goals proposed by the Ministry of Health. Based on PHPN and ESF, Rede Cegonha started in 2011, a strategy launched by the Ministry of Health, focused on promoting a care network for pregnant women to ensure humanized care during pregnancy, childbirth and the postpartum period, as well as reproductive planning. 9

As recommended by the Ministry of Health, care in this period should be performed preferably in the first trimester, with monthly consultations for greater care and effective monitoring while the pregnant woman should be attended by a doctor or nurse at least once in the first trimester, twice in the second trimester and three times in the third trimester of 
Map of Tocantins State - Proportion of pregnant women with vaccine on time (PWVT) in the interval from 2001 to 2015

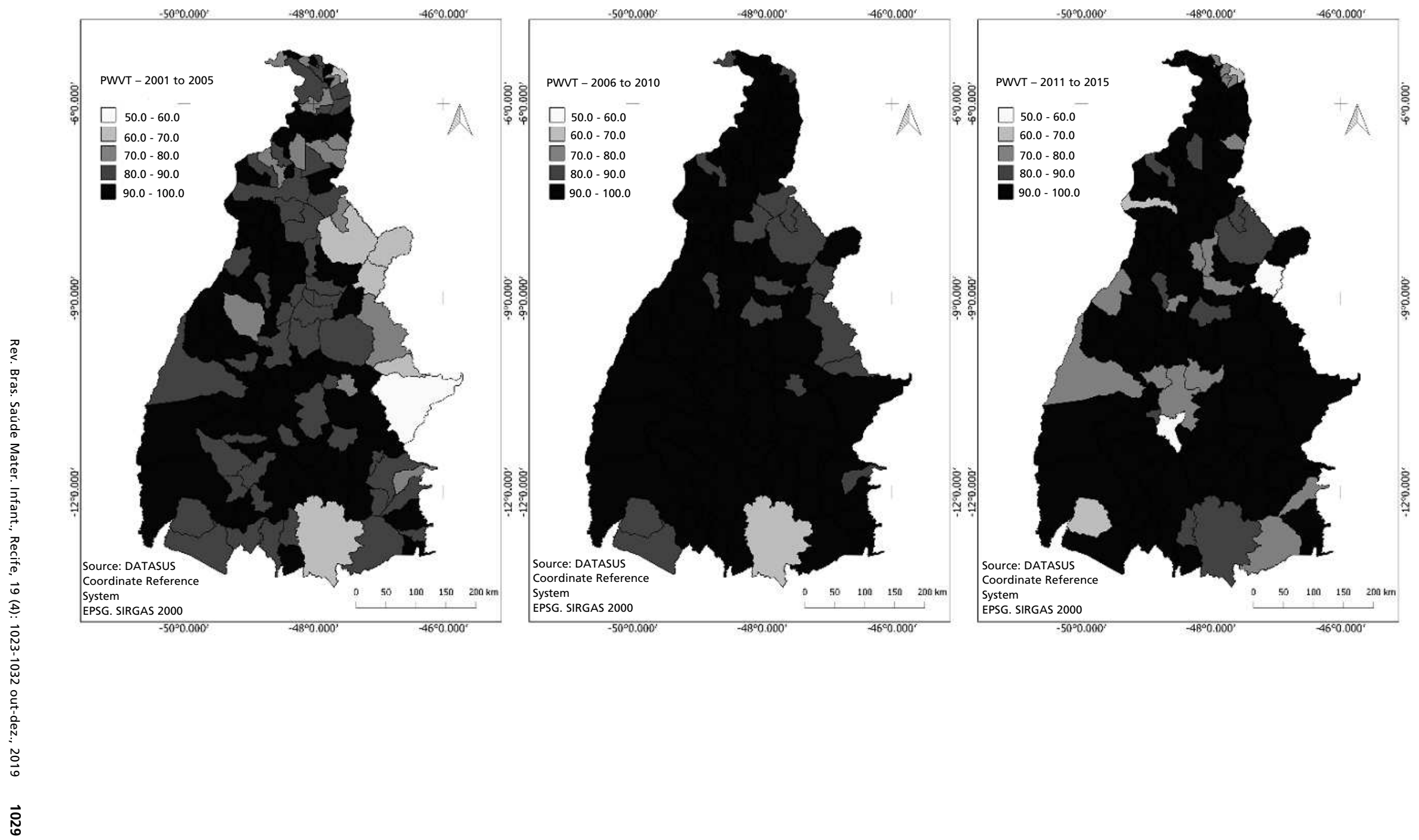


Table 1

Average indicators of the Women's Health axis in the ten largest cities in the State of Tocantins and in the State of Tocantins between 2001 to 2015 .

\begin{tabular}{llll}
\hline Municipality & APCPW & PPCFT & PWVT \\
\hline Araguaína & 1.13 & 81.32 & 92.52 \\
Araguatins & 1.30 & 71.45 & 90.00 \\
Colinas do Tocantins & 1.56 & 82.68 & 95.84 \\
Dianópolis & 1.46 & 77.19 & 92.63 \\
Guaraí & 2.05 & 86.40 & 96.18 \\
Gurupi & 1.83 & 79.17 & 90.77 \\
Palmas & 0.91 & 74.43 & 89.11 \\
Paraíso do Tocantins & 1.20 & 78.26 & 88.92 \\
Porto Nacional & 1.12 & 73.32 & 88.72 \\
Tocantinópolis & 1.03 & 81.82 & 95.29 \\
Tocantins & 1.23 & 73.38 & 91.97 \\
& & &
\end{tabular}

$\mathrm{APCPW}=$ Average prenatal care per registered pregnant woman; PPCFT= Proportion of pregnant women with prenatal care in the first trimester; PWVT= Proportion of pregnant women with vaccine on time.

pregnancy. 9 Thus, it was concluded that the adherence of pregnant women to early prenatal care in the state of Tocantins can be classified as good, with a value of $73.38 \%$ (Table 1 ) and having the average of all states in Brazil, in the same period, the percentage of $79 \%$. More prenatal care in the first trimester may have a beneficial effect on another indicator, as earlier prenatal care tends to increase the number of consultations and better adherence of the pregnant woman. ${ }^{15-17}$ Although this benefit has been found in other similar studies, 14,15 in the State of Tocantins it wasn't, given that even with the highest proportion of pregnant women with early prenatal care, the number of attendances per pregnant woman, shown in Table 1 and Figure 1, does not reach the minimum goals proposed by the Ministry of Health. This result may come from a discontinuous process in prenatal care, having as possible causes mainly disenchantment and distrust in the quality of services provided by Basic Health Units, ${ }^{16}$ as well as the difficulty in accessing health services and the low education level of the circumscribed population in the region. ${ }^{11}$

Thus, the state of Tocantins is atypical when compared with states in other regions and the northern region itself, $14-16$ where prenatal adherence occurs late and the adequacy of the number of visits is higher than early onset. The incentive through collective campaigns, the active home search with expansion coverage areas by ESF, a more agile process for scheduling appointments and demonstrating more attention to the complaints of pregnant women during consultations could serve as a more attractive aid and a mechanism for pregnant women to facilitate early access to prenatal care. 20

The indicator of the proportion of pregnant women with vaccines on time - PWVT (Figure 3) allows us to verify the percentage of pregnant women which have the tetanus toxoid vaccine on time. The Ministry of Health aims to ensure that $100 \%$ of pregnant women have the tetanus vaccine up to date, 18 which can be performed from the $20^{\text {th }}$ gestational week, according to the vaccination schedule of the Brazilian Society of Immunizations for pregnant women, but the number of doses is variable depending on the vaccination history of this pregnant woman. 21

The purpose of tetanus vaccine is to eradicate cases of neonatal tetanus, ${ }^{22}$ a disease that in the 1970 s was a serious public health problem due to its association with high morbidity and mortality rates, ${ }^{23}$ which is why therewas a need to implement a National Immunization Program in 1973, which contributed for the reduction of neonatal mortality rates from preventable causes, including neonatal tetanus. 24

Although the vaccine is freely available from UHS and there are frequent vaccination campaigns, the adherence to tetanus vaccine is still low in the country and generally does not reach half of the expected target audience.25,26 However, in Tocantins, the study of Figure 3 shows that the state has high proportions of vaccines in pregnant women, a process that has been observed since the beginning of 2001 and continues until the end of 2015, with a gradual increase in this proportion in most of the 
state, although there are some areasstill to note that suffered regressions in the second and third intervals. PHPN might be responsible for this situation, a program that aims to reduce maternal morbidity and mortality and creation of a scenario with more favorable neonatal prognoses 25,27; also Rede Cegonha strategy might gain some points too, and, of course, the National Immunization Program (PNI Portuguese acronym). PNI having contributed to the elaboration of several plans for reduction of preventable diseases, such as the Plan for the Elimination of Neonatal Tetanus, in 1992, a plan that aimed to identify larger municipalities atrisk for the disease and indicate vaccination for all women of childbearing age, between 15-49 years old, pregnant or not. 28 Other programs to assist municipalities in the process of capturing and stimulating tetanus vaccination in pregnant women emerged in 2003, promoted by the PNI.28 This fact may reflect the increase in the proportion of pregnant women with vaccine on time observed in the second interval (2006 to 2010) in Figure 3.

Thus, it can be concluded that Tocantins has satisfactory results, revealing that the planning and management of actions in the area of immunization are being sufficient and are gradually being improved. However, it is noteworthy the need for active search of pregnant women by health teams and also simple measures such as flexibility in the application of vaccines, to facilitate access and enable approximation of $100 \%$ for vaccination coverage, and also the promotion of awareness for all active professionals in the ESF to check the vaccination status of this group. ${ }^{9}$

Based on Table 1, it is observed in APCPW the degree of inadequacy of Tocantins (1.23 attendances / pregnant woman) to the goals of the Ministry of Health when compared to other states, such as São Paulo and Minas Gerais, who showed an average of five attendances per pregnant woman, or others such as Alagoas, Paraíba, Sergipe and Ceará who presented nine attendances per pregnant woman. ${ }^{9}$ In the North Region in Brazil, the adequacy toa sufficient number of consultations is $30.18 \%$, which is also far from the national average of $55.38 \% .15$ The PPCFT presented a wide variation in the states of the federation, with variation between $56 \%$, observed in Acre; $89 \%$, observed in São Paulo, and overall average of all states of $79 \%$, while Tocantins, although a little aheadfrom the other states in the North region, averaging $73.38 \%$, is still slightly below the overall average observed in Brazil. For PWVT, data from SIAB pointed out that $93 \%$ of pregnant women in Brazil9 were on time with vacci- nation, with Tocantins $(91.97 \%)$ in line with this general scenario.

Although online information systems serve as a means of ascertaining the scenario of a region, they still have many flaws. The non-disclosure of data by some municipalities favors underreporting and thus prevents their information from being computed for analysis, serving as a hindrance for a better analysis, hampering the development of better health policies to improve these same municipalities. Currently, most epidemiological studies find their main limitation at this point.

Given the above, it was possible to characterize prenatal care indicators in the state of Tocantins compared to the current Brazilian scenario, verifying that there are, in fact, inadequacies in specific sectors of the state, requiring extensive improvements in women's health related to UHS, especially in prenatal care. Among the three indicators analyzed, APCPW is the one that needs the most attention in the State of Tocantins, requiring major review of its policies to improve its indicator effectively, because although there has been some improvement over 15 years, this has been insufficient and it remains as a weak indicator. Improvements can be achieved through the development of campaigns and training to attract women into primary care and thereby improve these indicators. Moreover, although the PPCFT and PWVT indicators are satisfactory, it is important to continue the campaigns and policies adopted for them, in order to allow these indicators to be improved or at least be maintained.

\section{Authors' contribution}

The authors participated in the stages of conception, data collection, results evaluation and writing. All authors approved the final version of the manuscript. 


\section{References}

1. Brasil. Ministério da Saúde. Secretaria de Atenção à Saúde Departamento de Ações Programáticas Estratégicas. Política nacional de atenção integral à saúde da mulher: princípios e diretrizes. Brasília, DF; 2004. p. 82.

2. IBGE (Instituto Brasileiro de Geografia e Estatística) Censo Demográfico 2018. (acesso em 24 maio 2018) Disponível em: http://www.ibge.gov.br.

3. Coelho EAC, Silva CTO, Oliveira JF, Almeida MS Integralidade do cuidado à saúde da mulher: limites da prática profissional. Esc Anna Nery Rev Enferm. 2009; 13 (1): $154-60$.

4. Rodrigues ARM, Dantas SLC, Pereira AMM, Silveira MAM, Rodrigues DP. Gravidez de alto risco: análise dos determinantes de saúde. Sanare-Rev Políticas Públicas. 2017; 16 (1): 23-8

5. Viellas EF, Domingues RMSM, Dias MAB, Gama SGND, Filha MMT, Costa JVD, Bastos, MH, Leal MDC. Assistência pré-natal no Brasil. Cad Saúde Pública. 2014; 30 (Suppl.): S85-S100.

6. Cox JW, Hassard J. Triangulation in Organizational Research: a Representation. Organization. 2005; 12 (1) 109-33.

7. IBGE (Instituto Brasileiro de Geografia e Estatística) Divisão do Brasil e Mesorregiões e Microrregiões Geográficas. Rio de Janeiro: Ministério da Economia, Fazenda e Planejamento, 1990. 137p.

8. REDE Interagencial de informação para a saúde Indicadores básicos para a saúde no Brasil: conceitos e aplicações. 2. ed. Brasília, 2008. [acessado em 16 out. 2019]. Disponível em: http://tabnet.datasus.gov.br/tabdata/ livroidb/2ed/indicadores.pdf

9. Brasil. Ministério da Saúde. Secretaria de Atenção à saúde. Departamento de atenção básica. Qualificação dos Indicadores do Manual Instrutivo para as equipes de Atenção Básica. Brasília, DF; 2015.

10. Bertin J. A neográfica e o tratamento da informação. Curitiba: Ed. da UFPR; 1986.

11. Carvalho VCP, Araújo TVBD. Adequação da assistência Pré-Natal em gestantes atendidas em dois hospitais de referência para gravidez de alto risco do Sistema Único de Saúde, na cidade Recife, Estado de Pernambuco. Rev Bras Saúde Matern Infant. 2007; 7 (3): 309-17.

12. Brasil. Ministério da Saúde. Portaria $n^{\circ} 570$, de $1^{\circ}$ de Junho de 2000. Estabelece o Programa de Humanização no Prénatal e Nascimento. Brasília, DF, 1 jun 2000

13. Nunes JT. Qualidade da assistência pré-natal no Brasil: revisão de artigos publicados de 2005 a 2015. Cad Saúde Coletiva. 2016; 24 (2): 252-61.

14. Anversa ETR, Bastos GAN, Nunes LN, Dal Pizzol TDS. Qualidade do processo da assistência pré-natal: unidades básicas de saúde e unidades de Estratégia Saúde da Família em município no Sul do Brasil. Cad Saúde Pública. 2012; 28 (4): 789-800.

Received on April 26, 2019

Final version presented on August 28, 2019

Approved on September 3, 2019
15. Costa GRC, Chein MBC, Gama MEA, Coelho LSC, Costa ASV, Cunha CLF, Brito LMO. Caracterização da cobertura do pré-natal no estado do Maranhão, Brasil. Rev Bras Enferm. 2010; 63 (6): 1005-9.

16. Costa CSC, Vila VSC, Rodrigues FM, Martins CA, Pinho LMO. Características do atendimento pré-natal na Rede Básica de Saúde. Rev Eletrônica Enferm. 2013; 15 (2): 516-22.

17. Grangeiro GR, Diogenes MAR, Moura ERF. Atenção PréNatal no Município de Quixadá-CE segundo indicadores de processo do SISPRENATAL. Rev Esc Enferm USP. 2008: 42 (1).

18. Brasil. Ministério da Saúde. Secretaria de Atenção à Saúde. Departamento de Atenção Básica. Atenção ao Pré-Natal de Baixo Risco. Normas e Manuais Técnicos - Caderno de Atenção Básica ${ }^{\circ} 32$. Atenção ao Pré-Natal de baixo risco. Brasília, DF; 2012. 320 p.

19. Andreucci CB, Cecatti JG, Macchetti CE, Sousa MH. Sisprenatal como instrumento de avaliação da qualidade da assistência à gestante. Rev Saúde Pública. 2011; 45 (5): 854-63.

20. Domingues RMSM, Hartz ZMDA, Dias MAB, Leal MDC. Avaliação da adequação da assistência pré-natal na rede SUS do Município do Rio de Janeiro, Brasil. Cad Saúde Pública. 2012; 28 (3): 425-37.

21. Sociedade Brasileira de Imunizações. Calendário de vacinação SBIm Gestante - 2019/2020. 2019 [acessado em 31 jul 2019]. Disponível em: https://sbim.org.br/images/calendarios/calend-sbim-gestante.pdf

22. Vieira LJ, Oliveira MHPD, Lefèvre F. O uso da expressão "mal-de-sete-dias" por mães de crianças que morreram de tétano neonatal em Minas Gerais (1997-2002). Texto Contexto Enferm. 2006; 15 (1): 51-9

23. Murahovschi J. Tétano dos recém-nascidos: revisitado. Rev Paul Pediatr. 2008; 26 (4): 312-4.

24. França ISX, Simplício DN, Alves FP, Brito VRS. Cobertura vacinal e mortalidade infantil em Campina Grande, PB, Brasil. REBEn. 2009; 62 (2): 258-64.

25. Mattos LMBBD, Caiaffa WT, Bastos RR, Tonelli E. Oportunidades perdidas de imunização antitetânica de gestantes de Juiz de Fora, Minas Gerais, Brasil. Rev Panam Salud Publica. 2003; 14 (5): 350-4

26. Martinelli KG. Adequação do processo da assistência prénatal segundo os critérios do Programa de Humanização do Pré-natal e Nascimento e Rede Cegonha. Rev Bras Ginecol Obstet. 2014; 36 (2): 56-64.

27. Serruya SJ, Cecatti JG, Lago TDGD. O Programa de Humanização no Pré-natal e Nascimento do Ministério da Saúde no Brasil: resultados iniciais. Cad Saúde Pública. 2004; 20 (5): 1281-9.

28. Brasil. Ministério da Saúde. Secretaria de Vigilância em Saúde. Programa Nacional de Imunizações: 30 anos. Brasília, DF; 2003. p. 212. 